\title{
Cultural Homelessness, Social Dislocation and Psychosocial Harms: An Overview of Social Mobility in Hong Kong and Mainland China
}

\author{
Jason Hung ${ }^{1}$ \\ ${ }^{1}$ Department of Sociology, the London School of Economics, London, the United Kingdom \\ Correspondence: Jason Hung. E-mail: sociowriting@jasehung.com
}

Received: November 10, 2019

Accepted: January 3, 2020

Online Published: April 30, 2020

doi:10.5539/ass.v16n5p1

URL: https://doi.org/10.5539/ass.v16n5p1

\begin{abstract}
In order to facilitate collective decision making and breed productivity, it is important to ensure societies operate in a fair and just manner. Chinese literature has a propensity of relying on sociological theories from the modern West, prompting the review essay to address theories of capital, social mobility, cultural preferences and otherwise based on leading western literature. This review essay addresses how an increase in social mobility of those from lower social origins results in cultural homelessness and social dislocation, in relations to the experiences of psychosocial harms. As per western studies, the review essay examines the extent of cultural homelessness, social dislocation and psychosocial harms faced by upwardly mobilising cohorts in Hong Kong and China. To conclude, the essay argues upwardly mobilising cohorts in Hong Kong and China are likely to experience cultural homelessness, and the corresponding cohorts in China face salient problems of social dislocation. The encounters of cultural and social dilemmas are associated with the experiences of psychosocial harms for both populations.
\end{abstract}

Keywords: sociology, social mobility, social class, cultural preference, psychosocial wellbeing

\section{Introduction}

Fairness and justice are overarching factors in human enhancement, in terms of biological, psychological, or social attributes. Human enhancement refers to an increase in opportunities of leading a good life (Savulescu, 2006). Fairness is interpreted as a state where each individual enjoys chances to reach their desired social destination, irrespective of their origin. Specifically, no one should be inhibited from maximising their potentials by their background or nature (HMG, 2011, pp. 6, 11). Each person is deemed a free agent, with the ability to develop and utilise their skills and talents. Justice refers to a state where every free agent receives a deserved reward equivalent to their contributions (Mijs, 2016, p. 17). Distributive justice asserts that the allocation of goods is morally just and fair as each individual is entitled to equal opportunities and distribution of endowments (Mijs, 2016, p. 26; Cohen, 1995, p. 199; Elster, 1986, p. 79). In a society, fairness can facilitate stakeholders' acceptance, and cooperation in the implementation, of decisions made (Gross, 2011, p. 150; Hophmayer-Tokich \& Krozer, 2008, p. 255). Justice, alternatively, can breed productivity, while minimising poverty, instability and conflicts (ILO, 2019). In contrast, injustice demotivates individuals to optimise production outputs (Mijs, 2016, p. 17).

Upper class individuals enjoy privileges that allow them to secure additional capital (Breed \& Rottman, 2013). Compared to Max Weber (1998, p. 44) and Tak Wing Chan \& John Goldthorpe (Bihagen \& Lambert, 2018, p. 2), Pierre Bourdieu interprets class from a broader perspective, arguing class is associated with how individuals feel either "entitled" or "dominated" within and beyond economic contexts (Savage, 2015, p. 46). Capital is a durable good which can generate a stream of goods or services for a duration (Shapovalova, 2013, p. 152). According to Bourdieu, class privilege exists in relation to access to capital, a resource he defines as "having pre-emptive rights over the future" (Savage, 2015, p. 46). Social mobility is a measure of how realistically individuals can improve their social position (HMG, 2011, p. 15). Western literature argues increasing social mobility among relatively disadvantaged populations creates more space for them to claim capital in the long-term. In doing so, the allocation of goods or services is increasingly equalised (HMG, 2011, p. 6; Bottero, 2009, p. 9; Atkinson, 2010, p. 40). As a result, societies are able to operate in a fairer and more just manner.

However, Chinese literature fails to assess whether increasing social mobility is a prominent factor in maintaining a fair and just operation of society. In July 1997, Hong Kong, a former British enclave, reverted to 
mainland Chinese governance. Hong Kong culture is redolent with mainland Chinese influences, particularly a Confucian legacy, which in part, emphasises the importance of, and associations between, academic and professional success (White \& Goodman, 2006, p. 12). Nevertheless, the implementation of the principle of "One Country, Two Systems" should have ensured that Hong Kong can retain its distinct commercial, legal and political identity from mainland China. For example, under the principle, Hong Kong enjoys the autonomy and independence to exercise the frameworks of equality before the law, private ownership of property and a range of human rights (HKG, n. d.). The shortage of these rights or freedom in mainland China makes it necessary to understand whether increasing social mobility of the relatively disadvantaged cohorts in Hong Kong and mainland China results in distinct levels of fairness and justice.

Chinese literature has a propensity of relying on sociological theories from the modern West rather than formulating its own body of theory (Huang, 2005, p. 94). Therefore, this article adopts Bourdieu's interpretation of capital. He identifies three types of capital: economic, social and cultural (Savage, 2015, p. 46; Savage, Devine, Cunningham, Taylor, Li, Hjellbrekke, Roux, Friedman, \& Miles, 2013, p. 223; Atkinson, 2015, pp. 62-3; Atkinson, 2010, p. 11). Economic capital encompasses individual wealth, income and property aggregation (Atkinson, 2015, p. 62). Social capital comprises resources based on social networks and associations with certain bodies, families and names which can help generate life chances (Shapovalova, 2013, p. 156; Savage, 2015, p. 62; Savage et al., 2013, p. 223; Atkinson, 2015, p. 63). Cultural capital, at root, refers to "intelligence" and is measurable through educational attainment (Atkinson, 2015, p. 63; Atkinson, 2010, p. 80; Chan, 2018, p. 186). It also includes cultural knowledge in the forms of, for example, music, literature and arts, and linguistic competence (Atkinson, 2010, p. 46; Payne, 2013; Eijck, 1999, p. 310). Individuals with more initial reserves of cultural capital are associated to further academic and occupational successes (Friedman, 2012, p. 470).

Among Hong Kong and mainland Chinese citizens of lower social origins, upward mobility may help accumulate more cultural, social, and especially economic capital. However, this article addresses why these cohorts, while experiencing greater economic stability, may suffer cultural homelessness and social dislocation, two conditions which may also worsen their mental and psychosocial wellbeing. This article argues a fair and just societal system cannot be realised by simply entitling more opportunities for upward mobility to those from lower social origins in both Hong Kong and mainland Chinese contexts. The article concludes why increasing social mobility for relatively disadvantaged population results in cultural, social, psychological and mental harms on them, in part, because of their lower social origins.

\section{Cultural Omnivourousness}

Bourdieu argues individuals produce habitus, a term referring individuals" "dispositions formed out of practical engagement with the materially shaped environment shared by those close in social space" (Atkinson, 2010, pp. 11, 71; Atkinson, 2015, p. 66; Goldthorpe, 2007, p. 22). In Distinction: A Social Critique of the Judgement of Taste, Bourdieu (1979) emphasises that cultural preferences are securely anchored through perception, judgment and action generated by the social conditions prevailing in families, education systems and the milieu of adulthood. The structure of habitus prompts the delivery of the "structuring" dispositions of perception, which guide and develop in-group individuals' social practice and cultural tastes respectively (Friedman, 2012, p. 469; Friedman, 2014, p. 361). Bourdieu argues individuals reproduce cultural capital harmoniously, where each individual is in a position to reproduce and strengthen the structure of the distribution of cultural capital in accordance with their classes, and material and symbolic interests (Bourdieu \& Passeron, 1977, p. 11). Additionally, once individuals are provided with the social power for imposition and inculcation - as teachers, parents, friends or otherwise - they are then given the opportunities to exert specific cultural influences on others (ibid, p. 7).

Bourdieu claims dispositions from habitus remain unified through time in most circumstances (Bourdieu, 1984, p. 101). Individuals from upper class habitus have the competence, tolerance and openness essential to appreciate, and dominate the appreciation of, "highbrow" cultures. Bourdieu (1998, p. 9) argues these "highbrow" cultures - in the forms of, for example, operas and symphonies - are often seen by "dominant" upper class as "legitimate" cultural preferences - tastes that are granted authority and recognition as the dominant aesthetic (Atkinson, 2015, pp. 68-9). In contrast, "lowbrow", inferior cultural preferences predominantly enjoyed by the lower classes are labelled as "illegitimate" (Friedman, 2014, p. 363; Daenekindt \& Roose, 2014, p. 83; Bauman, 2004, p. 40). Despite the consumption of "illegitimate" cultures may not represent nobility, increasing number of individuals from the upper class are willing to accept such cultures. Individuals in higher social positions are exhibiting cultural omnivourousness (Daenekindt \& Roose, 2014; Chan \& Turner, 2017, p. 576), or what Sam Friedman (2012, p. 468) characterises as "inclusive omnivores". 
Alternatively, the upwardly mobile cohorts are originally exposed to "lowbrow", illegitimate cultures. However, when the cohorts achieve upward social mobility, their access to "highbrow" cultures becomes viable (Daenekindt \& Roose, 2014, p. 85). Despite the increase of their social position, these cohorts usually maintain the bond with individuals - such as families, relatives and friends - from their origin, rendering a continuous consumption of "lowbrow" cultures. As a result, individuals from lower social origins but upper social destinations are also likely to exhibit a broad cultural repertoire (Daenekindt \& Roose, 2014, p. 87; Sorokin, 1927). A study of the Flemish population in Belgium, Daenekindt \& Roose (2014, p. 94) supported the heterogeneity in social experience facilitates the flexibility of cultural consumption from the omnivorous cohorts of lower origins.

Cultural boundaries are weakening (Chan \& Turner, 2017, p. 577). "Highbrow" cultural profiles do not preclude individuals from lower social origins. Such a cultural phenomenon highlights Bourdieu and Jean-Claude Passeron (1977, p. 7)'s argument that individuals have cultural influences on others, while they are simultaneously strengthening their own cultural habitus. Such a phenomenon is, in part, facilitated by the opportunities of social mobility. The increasing cultural omnivourousness of those upwardly mobilising implies upward social mobility grants individuals more chances to develop a broad range of cultural capital, irrespective of their social origin or nature. However, such an understanding overlooks the prices during the process of mobility, in addition to over-optimising the cultural gains at social destination. Within habitus of the upper classes, members have been close, and unified, in a social space through time. Individuals enjoying upward mobility, who attempt to gain entry to the elite habitus, may not find the appropriation of upper-class cultural tastes or social practice a smooth process.

\section{Cultural Homelessness}

To understand the mental and psychological prices of upward mobility, Pitirim Sorokin (1959)'s "dissociative thesis" should be considered. Sorokin highlights the negative association between upward mobility and subjective wellbeing (SWB). Upwardly mobile individuals may "never become fully accustomed to life in a new and alien class position". Here "new and alien class position" refers to the destination individuals reach by an increase in social mobility (Hadjar \& Samuel, 2015, p. 49). Sorokin believes upwardly mobile individuals struggle with attachment to, but detachment from, particular class cultures (Friedman 2016 p. 133). During the process of upward social mobility, "man more often cuts off the ties which bind him to his native place, occupation, party, state, religion, family, citizenship, and so on" (Sorokin, 1959, p. 523). However, upwardly mobile individuals fail to totally overcome the influence of their social origin, restricting the ability to acclimatise to their social destination (Daenekindt, 2016, p. 16). Simultaneously, they struggle to maintain connections with their families of origin and are aware of the increasing distance from their roots (Chan, 2018, p. 156; Friedman, 2016, p. 141). This process of detachment can be extremely stressful, particularly as cultural and personal ties to both social origin and destination are lost (Friedman, 2016, p. 133; Sorokin, 1959, p. 523). In State Nobility, Bourdieu (1998, p. 106-7) describes such an experience as "double isolation". From his own experience, he dubs the discrepancy between his educational attainment and low social origin a habitus clivé - a sense of self "torn by contradiction and internal division" (Friedman, 2016, pp. 129-30). As a result, these culturally lost cohorts whose habitus are "split between two worlds" are inclined to develop psychosocial challenges, including discomfort, anxiety, distress and psychoses (Chan, 2018, p. 156; Sorokin, 1959, p. 519; Chan, 2018, pp. 183-4; Daenekindt, 2016, p. 21).

Unlike Peter Blau (1956), who believes individuals have the propensity to relinquish their primary disposition of the habitus, Bourdieu argues the original disposition is ingrained, perpetual and reproductive (Naudet, 2008, p. 416; Friedman, 2016, p. 131). These cohorts often experience the influence of "push-pull" factors. They are pushing towards the renouncement of, while pulling back towards, their social origin and cultural identities of their origin (Naudet, 2008, p. 416; Friedman, 2012). Friedman (2012, p. 484) dubs these cohorts culturally homeless as they are "dislocated from a recognisable cultural habitus, permanently caught with one foot in two different taste cultures".

Goldthorpe (1980, p. 331) contests this point, arguing that individuals raising their social mobility are likely to be surrounded by those who experience similar paths of upward mobility and share similar cultural tastes and lifestyles (Friedman, 2014, p. 355). Consequentially, these cohorts remain connected to a familiar habitus on their way up the social position. However, Friedman (2012, p. 471) criticises Goldthorpe's arguments are based on data collected in 1972-4, which have not been systemically updated. In his data collection, his interviews were restricted to male samples and a poor response rate of $27 \%$ was recorded. Goldthorpe (1980, pp. 244-5)'s emphasis on the positive force of upward mobility was based on just four direct quotes from samples (Friedman, 2014, p. 357). Goldthorpe's findings display unsatisfactory validity and poor applicability in a contemporary 
context.

Echoing Goldthorpe's findings, Chan (2018, p. 188) focuses on the analysis of the British Household Panel Survey (BHPS) 2007-8 and Understanding Society 2011-14, and found that upward mobility is positively associated with job satisfaction, overall life satisfaction and happiness. Chan $(2018$, p. 199) also fails to find any evidence suggesting upward mobility links to the development of psychological distress. Additional scholars, including Gordon Marshall \& David Firth (1999) and Jason Houle \& Molly Martin (2011) find no evidence to support Sorokin's dissociative thesis.

Blau argues social mobility imposes cross-boundary pressure on the upwardly mobile cohorts. The significant differences of cultural exposure between social origin and destination render a rather destabilised habitus shared by the upwardly mobilising cohorts. They are then likely to suffer from uneasiness and emotional disequilibrium (Daenekindet \& Roose, 2014, p. 85). In this instance, internal judgment rather than external criticism may be a more crucial factor in the initiation of painful, disorientating sentiments (Friedman, 2016, p. 139). Some individuals can force themselves to adapt to habitus of upper classes, but in doing so they may also suffer further from cultural contradiction and a betrayal of what they identify as authentic selves (ibid, p. 140). Others from the same cohorts were unable to communicate with confidence regarding their appreciation of legitimate cultural tastes. Simultaneously, their cultural tastes developed from the origin lack legitimacy and is often seen as unacceptable within habitus of upper classes (Friedman, 2014, p. 363). As a result, these individuals struggle to form intimate relationships and suffer from psychosocial vulnerability and mental disorders (Chan, 2018, p. 198; Chan, 2017, pp. 185, 199).

Increased social mobility may successfully help individuals obtain more life chances and secure upper social positions. However, such a change in social position often comes with a high price. Individuals of low social origins raise their mobility at the expense of cultural dislocation and homelessness. Consequentially, these cohorts' psychosocial and mental wellbeing is harmed.

\subsection{Hong Kong and Mainland China}

In both Hong Kong and mainland Chinese societies, the belief in traditional Confucian values is pronounced (Yao, 2000; Qing, 2011; Lin \& Ho, 2009). The core Chinese culture of Confucianism emphasises the importance of filial piety (Chan \& Leung, 2015). Filial piety promotes, in part, children's respect, obedience and academic success. This is because academic achievements of young generations link to family pride, professional success and increased social mobility (Zhan \& Montgomery, 2003; Chao, 1996; Ho, 1996).

In Hong Kong, those who learn and work hard enough to secure associate professional jobs have a potential to realise upward mobility (Lee, Wong \& Law, 2007, p. 14). In order to maximise children's academic excellence and raise familial social position in the long-term, Hong Kong Chinese parents of lower origins often set high expectations around their children's academic performance (Shek, 1997). Unlike those of upper socioeconomic status (SES), children of lower social origins lack the opportunities to develop legitimate cultural tastes - for example playing piano and receiving international school education on a self-financing, non-government funded basis (Byun, 2016; Ma, Wong, Lau, \& Pun, 2009, p. 246; Poon, 2012; HKG, 2018). Here SES is measured by parental education, parental occupation, family wealth, and home educational resources (Byun 2016). Local, non-international, schools are inclined to replace cultural subjects, including music and physical education lessons, with academic subjects due to the emphasis on students' academic success (Ho, 2006, p. 226; Morris, 1997, p. 338). An estimate of $70 \%$ of local secondary school students spend their spare time on private supplementary tutoring in order to better prepare for school examinations and university entrance public examinations (Byun, 2016). These imply the limited opportunities for Hong Kong's local school students to explore their cultural possibility after-school or on holiday. Most of them therefore fail to develop legitimate cultural tastes, as necessary to enter upper class habitus of upper classes (Friedman, 2014, p. 363).

Although local school students of lower social origins enjoy listening to music as a cultural activity, these students predominantly listen to citywide commercialised popular music which is inauthentic, manipulative and unsatisfying (Law \& Ho, 2004). The Hong Kong Youth Services (2004) interviewed 1,044 local primary school students and asked them to list out ten most popular public figures of their interest. Results revealed Hong Kong commercialised popular music celebrity group "Twins" topped the ranking (Ho, 2006, p. 227). These individuals of lower social origins are rarely, if ever, encouraged to express legitimate cultural tastes in their childhood and adolescence in which their cultural preferences per se are restrictively "lowbrow". As Friedman (2016 p. 140) indicates, even if these cohorts are forced to adapt to habitus of upper classes, they may encounter cultural contradiction and a betrayal of their authenticity, outcomes that lead to cultural homelessness.

Upwardly mobile cohorts can only strive for academic success by excelling in examinations, rather than through 
holistic personal development. However, the greater their educational attainment, the less likely they are to sacrifice personal interests to follow parental instructions, as required by filial piety (Yeh, Yi, Tsao, \& Wan, 2013). As a result, educational attainment may be negatively associated with the attachment to filial piety, as a core cultural value in Chinese societies (Shek \& Chan, 1999; Ma, 2001).

Hong Kong citizens lack cultural confidence to claim legitimate cultural resources beyond academic credentials. For example, those from suburban areas enjoy fewer professional opportunities, including workshop-based trainings and internship opportunities. They are therefore discouraged from improving their soft skills, including communication and presentation skills (Spires \& Cox, 2016, p. 2). The inadequacy of soft skills development further undermines the cultural confidence of those from lower origins. This article, by no means, rules out the possibilities that upwardly mobile individuals from Hong Kong of poor origin can endeavour to broaden their cultural profiles and achieve cultural omnivourousness. However, beyond academic expertise, as per what Friedman (2014 p. 363) mentions, these cohorts may be disinclined to engage in communications which require pervasive cultural knowledge. These cohorts also have the propensity to renounce part, if not all, of the obligations of, and attachment to, filial piety. As Sorokin (1959) emphasises, these cohorts may never fully accustom to life in a new and alien class position (Hadjar \& Samuel, 2015, p. 49). This is because the original dispositions of these cohorts are ingrained, perpetual and reproductive (Naudet, 2008, p. 416; Friedman, 2016, p. 131). Consequentially, those detached from filial piety have a greater risk of developing depressive symptoms than individuals who are embracing filial piety due to cultural emptiness (Cheng \& Chan, 2006). To some extent, individuals of upward mobility are culturally detached, dislocated and isolated, leading to a decrease in their cultural sense of belonging.

In mainland China, individuals who migrate to cities for work enjoy more opportunities of increased mobility (King \& Skeldon, 2010). However, they are, concurrently, culturally and mentally disadvantaged in cities. It is noteworthy that rural education is always subject to poor teaching facilities and teacher quality (Wang, 2002, p. 133; Wang \& Gao, 2013, pp. 67, 71; Golley \& Kong, 2013, pp. 229, 245-6; Ding \& Lehrer, 2012, p. 199). Also, local citizens in rural, agricultural provinces face high unemployment and poor income levels (Chan, forthcoming). In order to improve financial wellbeing and social position, 262 million rural villagers and their children have migrated to cities for better job and educational opportunities by the end of 2013 (Fong \& Tong, 2015, p. 1087). However, the migrant cohorts often encounter acculturation barriers (Lin, Li, Wang, Hong, Fang, Qin, \& Statntion, 2011). For example, individuals of rural origin may be non-Mandarin native speakers, while city dwellers predominantly communicate in Mandarin. Those who communicate in rural dialects - an example of illegitimate cultural capital indicating lower social origins - encounter substantial language barriers in cities (Dello-lacovo, 2009, p. 243).

Apart from language competency, individuals of lower social origins suffer from additional challenges in cities as they possess fewer cultural resources. According to higher education admission policies, students demonstrating talents in the arts and sports are awarded bonus points in admissions. Those of rural origin, however, rarely have the access to these expensive extracurricular activities, leaving them further disadvantaged in terms of tertiary education entry (Zhao, 2014, p. 148). Their slim opportunities of entering elite higher education further restrict their life chances to maximising cultural potentials. Consequentially, the rural origin prompts disproportionately limited opportunities to secure cultural resources they deserve, despite an increase in social mobility (Luo, Tong, \& Cheung, 2018, p. 250). While they climb up their social positions, they encounter difficulties to accustom to any recognisable cultural habitus in urban destination, leading to what Friedman (2012, p. 484) refers as cultural homelessness.

Baoling Zhong, Tie-bang Liu, Sandra Chan, Dong Jin, Chi-yi Hu, Jing Dai \& Helen Chiu (2015, p. 2), and Yang Cao \& Zhenhui Liu $(2015$, p. 464) found that migrant cohorts with poor educational attainment are particularly likely to develop depressive symptoms. Here poor educational attainment refers to those with an education of junior high school level or below. Similar to their Hong Kong counterparts, the upwardly mobilising cohorts of lower social origin in mainland China are likely to display some extent of mental challenges, especially when they lack the cultural legitimacy.

\section{Social Dislocation}

Self-discrepancy theory argues individuals experiencing and perceiving inconsistencies between their actual and ideal selves are likely to develop dejection-related emotions. These include disappointment, frustration and dissatisfaction. In theory, upward mobility should reduce the differences between actual and ideal selves, and improve individual wellbeing (Zhou, Wu, Zou, \& Williams, 2017, p. 139). However, this theory overlooks external factors that can worsen individual wellbeing during upward mobility. In Distinction: A Social Critique 
of the Judgement of Taste, Bourdieu (1979) believes the symbolic differences of lifestyles prompt the ranking of individuals within social structures. The socially stable upper classes may denigrate their upwardly mobile counterpart from lower origins, derisively labelling the latter (Atkinson, 2015, p. 45). In The Love of Art: European Art Museums and Their Public (1969), Bourdieu, Alain Darbel \& Dominique Schnapper revealed the discomfort and feeling of not being "at home" encountered by upwardly mobilising cohorts from working-class origin. As mentioned in the "dissociative thesis", the mobilising cohorts may have a decreasing strength in social bonds to his native family, citizenship and place through time (Sorokin 1959 p. 523). Detachment may result in social isolation, loneliness and higher chances of suicide (Chan 2017 pp. 183-4; Chan 2018 p. 198). In Hong Kong, the upwardly mobile cohorts fail to accumulate a satisfactory level of social connections for professional development, weakening their attachments to social origins and destinations. In mainland China, internal migrants often face social detachment from both their rural origins and urban destinations.

\subsection{Hong Kong and Mainland China}

Upward mobility of those from lower social origins is, in part, facilitated by strong social networks (Ma $2009 \mathrm{p}$. 246). Here strong networks refer to a circle of individuals who are closely connected, and each is, simultaneously, weakly tied to ample other connections who can pass on school, job or business information (Chan, 1994, p. 28). In Hong Kong, the receipt of higher education is significantly correlated to family background. However, the enrolment rate of youths from among the top 10 percent of the richest families $(48.2 \%)$ for university degrees was 3.7 times that of those living in poverty $(13 \%)$ in 2011 . The same ratio was only 1.2 percent in 1991 (Lee, 2016, p. 14). The poor are prohibited to study for university or forced to read a degree at the expense of their living standards (ibid, p. 15). Despite those from lower origin maybe able to complete their university degrees, very often are they subject to low employability due to an absence, or a lack, of family connections (ibid).

Geographically speaking, Hong Kong citizens from suburban areas in New Territories have disproportionately achieved lower educational attainment and social mobility than Hong Kong citizens on average. Robert Spires \& Jt Cox (2016, p. 2) argue the disintegrating social networks documented in suburban areas bar individuals from upward mobility and worsen their social marginalisation. The lack of metropolitan social networks is positively associated with the insufficiency of language and cultural affluence (ibid). For example, youths from suburban areas lack of the confidence to speak English in social and professional settings due to their limited opportunities to practice oral English (ibid). This claim echoes Bourdieu \& Passeron (1977, p. 6)'s argument made in Reproduction $n$ Education, Society and Culture who highlight the stronger the strength of social connections, the more the amount of cultural assets owned by individuals. Without adequate social resources from their origins, upwardly mobilising cohorts are denied the opportunities to secure their deserved life chances and discouraged from maximising social attachments at destination.

Individuals reaching services class equally rely on work contacts, including employers and former colleagues, and family contacts for professional success (Chan, 1994, p. 150). Healthy social ties between colleagues are crucial to the enhancement of knowledge-sharing behaviours, helping individuals find better job opportunities than their current or previous profession (Chow \& Chan, 2008 p. 463). Family contacts are particularly useful if individuals prefer a change in professions (Chan, 1994, p. 144).

These studies suggest that upwardly mobile individuals of lower social origins but upper destinations face a shortage of family and metropolitan networks, as necessary to build up academic and professional success, and cultural confidence. These upwardly mobilising cohorts from lower origins suffer from social marginalisation and fail to enjoy a fair share of life chances. As a result, to some extent, these cohorts develop a sense of discomfort from upward mobility, leading to social dislocation (Spire \& Cox, 2016, p. 2).

In mainland China, according to Article 5 of The Temporary Regulation on the Administration of Cross-Provincial Employment of Migrant workers, issued by the Ministry of Labour in 1994, urban job opportunities for the migrant cohorts are restricted, a policy which is, in part, to ensure employment security for local city dwellers (Li 2006 p. 59). Since local city dwellers are prioritised to take over jobs with better working conditions, their migrant cohorts are often subject to very long working hours, limiting time available to maintain social bonds with family or build metropolitan networks (Li, Wang, Ye, Jiang, Lou, \& Hesketh, 2007, pp. 717-8). Existing Chinese literature argues socioeconomic subordination is associated with higher levels of perceived discrimination and lower mental health scores at $\mathrm{p}<0.00001$ (Hu \& Chen 2012; Jin, Wen, Fan, \& Wang, 2012; Lin et al., 2011; Yang, Xu, Li, Rockett, Zhu, \& Barnes, 2012). In addition, the migrant cohorts experience social exclusion, including the separation of networks from local urban residents due to uncommon dialects, customs and denigration as "second-class citizens" by local city dwellers (Zhan 2011 p. 265). Such a social phenomenon corresponds to Bourdieu (1979)'s argument that citizens are ranked within the contemporary 
social structures.

These discriminatory encounters result in higher degrees of social stress and barriers to acculturation, which in turn jeopardise rural migrants' psychosocial wellbeing (e.g. Liu, Tian, \& Yan, 2009; Qian, Wang, \& Wang, 2008). A total of 48 existing studies revealed that rural migrants facing greater social exclusion displayed additional psychosocial symptoms. These included interpersonal sensitivity, depression, anxiety, hostility, phobic anxiety and paranoid ideation (e.g. Zhong et al., 2013 p. 1571; Liu et al., 2009; Li, Ren, Sun, Cheng, \& Zhang, 2008; Liu, Luo, Liu, \& Zhou, 2008).

While rural migrants are more likely to send money to family members left behind in rural villages, studies found that many do not engage in regular contact via telecommunications. Their migrant children also lose social ties to rural peers due to geographical barriers and discrepancies in lifestyles (Luo et al. 2018 pp. 249-50; Liu, Sun, Zhang, Wang, \& Guo, p. 87). Consequentially, the migrant cohorts are disassociated with social groups from both rural origin and urban destination. Urban elites, alternatively, who are city locals, are able to avoid the kind of social dislocation their migrant counterparts experience. From socioeconomic discrimination to social dislocation, the migrant cohorts fail to enjoy a fair share of life chances while climbing up the social ladder. This occurs, in part, because of their rural origin, meaning that they cannot receive equal opportunities in cities, to which local city dwellers are entitled. Despite the acknowledgement that internal migration is a means of upward mobility, the migrant cohorts suffer from an unfair and unjust allocation of social resources.

\section{Conclusions}

It is undeniable that increasing social mobility creates corresponding opportunities to improve reserves of cultural, social and economic capital. However, for those of lower social origins, they are claiming, but also denied from accessing, capital. In Hong Kong, upwardly mobilising cohorts have earned deserved academic credentials. However, while they are pursuing academic success, they sacrifice their spare time to foster legitimate cultural tastes, discouraging the realisation of non-academic, holistic development. In mainland China, migrating to cities for academic and professional successes is an opportunity for those from low rural origin to improve their Mandarin proficiency. However, migrants are also subject to daily acculturation and language barriers due to their non-fluent proficiency in Mandarin. The cultural contradiction experienced by the upwardly mobilising cohorts often results in habitus clivé, in which members of these cohorts struggle with internal division. As a result, they become culturally homeless.

Upward mobility is supposed to change individuals' class identity, either to disassociate them from lower classes or to assimilate them into upper classes (Wong, 2010). However, when there is a significant inconsistency between the identities of social origin and destination, very often are individuals of upward social mobility culturally lost due to the inability to claim a fair, deserved share of resources. As such, this article demonstrates, from a cultural perspective, how increasing social mobility alone fails to serve as a key way to ensure societies in Hong Kong and mainland China operate in a fair and just manner.

Worse still, Hong Kong and mainland Chinese individuals of upward social mobility are subject to social marginalisation and denigration respectively due to their lower origins. Based on Bourdieu's "dominated" and "entitled" argument, the urban elite groups dominate most metropolitan social resources, denying the entitlement of a fair share of such resources to the upward mobilising cohorts. For individuals of upward mobility, they encounter difficulties to locate themselves confidently in social and professional settings. To conclude, from a social perspective, this article argues an increasing social mobility alone fails to guarantee the operation of a fair and just society.

A fair and just society should help promote human enhancement, in terms of psychological attributes or otherwise. An increase in social mobility for those from relatively disadvantaged background, however, worsens their mental and psychosocial wellbeing to some extent. According to Hong Kong, mainland Chinese and Western literature, the experiences of cultural homelessness and social dislocation are negatively associated with mental and psychological wellbeing. Upward social mobility itself entails significant mental and psychosocial sacrifice, inhibiting those climbing up the social positions from maximising their potentials from a holistic perspective.

\section{References}

Atkinson, W. (2010). Class, Individualisation and Late Modernity. In Search of the Reflexive Worker. Basingstoke: Palgrave Macmillan.

Atkinson, W. (2015). Class. Oxford, Polity Press.

Bauman, Z. (2004). The Meaning of Work: Producing the Work Ethic. Work. Consumerism and the New Poor 
(pp. 5-22). Maidenhead: McGraw-Hill Education.

Bihagen, E., \& Lambert, P. (2018). Can Class and Status Really be Disentangled? Research in Social Stratification and Mobility, 58(1), 1-10. https://doi.org/10.1016/j.rssm.2018.08.001

Blau, P. (1956). Bureaucracy in Modern Society. New York, NY: Crown Publishing Group.

Bottero, W. (2009). Class in the 21 st Century. In K. Sveinsson (Ed.), Who Cares About the White Working Class? (pp. 7-14). London: Runnymede Perspectives.

Bourdieu, P. (1979). La distinction: critique sociale du jugement [Distinction: A Social Critique of the Judgement of Taste]. Paris: Editions de Minuit.

Bourdieu, P. (1984). Distinction: A Social Critique of the Judgement of Taste. Cambridge, MA: Harvard University Press.

Bourdieu, P., \& Passeron, J. (1977). Reproduction in Education, Society and Culture. London: SAGE Publications.

Bourdieu, P., Darbel, A., \& Schnapper, D. (1966). L'amour de l'art: les musées de'art et leur public [The Love of Art: European Art Museums and Their Public]. Paris: Editions de Minuit.

Bourdieu, P. (1998). The State Nobility: Elite Schools in the Field of Power. Stanford, CA: Stanford University Press.

Breen, R., \& Rottman, D. (2013). Class Stratification: A Comparative Perspective. London: Routledge.

Byun, S. et al. (2016). Children's Highbrow Cultural Activities and Academic Achievement in Hong Kong. In G. Kao, \& H. Park (Eds.), Family Environments, School Resources, and Educational Outcomes (Research in the Sociology of Education, Vol. 19) (pp. 123-148). Pennsylvania, PA: Emerald Group Publishing Limited.

Cao, Y, \& Liu, Z. (2015). Poverty and Health: Children of Rural-to-Urban Migrant Workers in Beijing, China. Social Indicators Research, 123(2), 459-477.

Chan, K. (Forthcoming). The Encyclopedia of Global Migration. New York: Blackwell Publishing.

Chan, S., \& Leung, C. (2015). Factor Structure of the Screen for Child Anxiety-Related Emotional Disorders (SCARED) in a Community Sample of Hong Kong Chinese Adolescents. Child Psychiatry \& Human Development, 46(5), 671-682. https://doi.org/10.1007/s10578-014-0509-8.

Chan, T. (1994). Social Mobility in Hong Kong (Doctoral thesis). University of Oxford, Oxford.

Chan, T. (2018). Social Mobility and the Wellbeing of Individuals. The British Journal of Sociology, 69(1), 183-206. https://doi.org/10.1111/1468-4446.12285

Chan, T., \& Turner, H. (2017). Where Do Cultural Omnivores Come from? The Implications of Educational Mobility for Cultural Consumption. European Sociological Review, 33(4), 576-89. https://doi.org/10.1093/esr/jcx060

Chao, R., \& Sue, S. (1996). Chinese Parental Influence and their Children's School Success: a Paradox in the Literature on Parenting Styles. In S. Lau (Eds.), Growing Up the Chinese Way: Chinese Child and Adolescent Development. Hong Kong: Chinese University Press.

Cheng, S., \& Chan, A. (2006). Filial Piety and Psychological Well-Being in Well Older Chinese. Journal of Gerontology, 61(5), 262-269. https://doi.org/10.1093/geronb/61.5.P262

Chow, W., \& Chan, L. (2008). Social Network, Social Trust and Shared Goals in Organisational Knowledge Sharing. Information \& Management, 45(7), 458-465. https://doi.org/10.1016/j.im.2008.06.007

Cohen, G. (1995). Exploitation in Marx: what makes it unjust? In Self-Ownership, Freedom, and Equality (pp. 195-208). Cambridge: Cambridge University Press.

Daenekindt, S., \& Henk, R. (2014). Social Mobility and Cultural Dissonance. Poetics, 42(1), 82-97. https://doi.org/10.1016/j.poetic.2013.11.002

Daenekindt, S. (2016). The Experience of Social Mobility: Social Isolation, Utilitarian Individualism, and Social Disorientation. Social Indicators Research, 133(1), 15-30. https://doi.org/10.1007/s11205-016-1369-3

Dello-lacovo, B. (2009). Curriculum Reform and "Quality Education in China": An Overview. International Journal of Educational Development, 29(3), 241-9. https://doi.org/10.1016/j.ijedudev.2008.02.008

Ding, W., \& Lehrer, S. (2012). Incentives and the Quality of Teachers and Schools. In E. Hannum, \& Park, A. 
(Eds.), Education and Reform in China (pp. 191-204). New York, NY: Routledge.

Eijck, K. (1999). Socialisation, Education, and Lifestyle: How Social Mobility Increases the Culture Heterogeneity of Status Groups. Poetics, 26(5), 309-328. https://doi.org/10.1016/S0304-422X(99)00008-X

Elster, J. (1986). Exploitation. An Introduction to Karl Marx (pp. 79-102). Cambridge: Cambridge University Press.

Fong, E., \& Tong, Y. (2015). Can Family Financial Resources Buy Friends? Family Financial Resources and Friendship Patterns Among Migrant Workers in China. American Behavioural Scientist, 59(9), 1083-99. https://doi.org/10.1177/0002764215580615

Friedman, S. (2012). Culture Omnivores or Culturally Homeless? Exploring the Shifting Cultural Identities of the Upward Mobile. Poetics, 40(5), 467-489. https://doi.org/10.1016/j.poetic.2012.07.001

Friedman, S. (2014). The Price of the Ticket: Rethinking the Experience of Social Mobility. Sociology, 48(2), 352-368. https://doi.org/10.1177/0038038513490355

Friedman, S. (2016). Habitus Clive and the Emotional Impact of Social Mobility. The Sociological Review, 64(1), 129-147. https://doi.org/10.1111/1467-954X.12280

Golley, J., \& Kong, S. (2013). Inequality in Intergenerational Mobility of Education in China. China \& World Economy, 21(2), 225-49. https://doi.org/10.1111/j.1749-124X.2013.12013.x

Goldthorpe, J. et al. (1980). Social Mobility and Class Structure in Modern Britain. Oxford: Clarendon Press.

Goldthorpe, J. (2007). Cultural Capital: Some Critical Observations. Sociology Working Papers 2007-07. Oxford: University of Oxford.

Gross, C. (2011). Why justice is important. In D. Connell, \& Q. Grafton (Eds.). Basin Futures: Water reform in the Murray-Darling Basin (pp. 149-162). Canberra: ANU Press.

Hadjar, A., \& Samuel, R. (2015). Does Upward Social Mobility Increase Life Satisfaction? A Longitudinal Analysis Using British and Swiss Panel Data. Research in Social Stratification and Mobility, 39(1), 48-58. https://doi.org/10.1016/j.rssm.2014.12.002

HM Government (HMG) (2011, October 19). Opening Doors, Breaking Barriers: A Strategy for Social Mobility. Received from http://heer.qaa.ac.uk/SearchForSummaries/Summaries/Pages/HEER000112.aspx

Ho, D. (1996). Filial Piety and its Psychological Consequences. In M. Bond (Eds.), The Handbook of Chinese Psychology. Hong Kong: Oxford University Press.

Ho, W. (2006). Challenges to Values Education in Hong Kong School Music Education. Asia Pacific Journal of Education, 26(2), 225-241. https://doi.org/10.1080/02188790600937383

Hong Kong Government (HKG). (2018, May). Hong Kong: The Facts Education. Retrieved from https://www.gov.hk/en/about/abouthk/factsheets/docs/education.pdf

Hong Kong Government (HKG) (n.d.). One Country, Two Systems. Received from https://www.info.gov.hk/info/sar5/e12.htm

Hophmayer-Tokich, S., \& Krozer, Y. (2008). Public Participation in Rural Area Water Management: Experiences from the North Sea Countries in Europe. Water International, 33(2), 243-257. https://doi.org/10.1080/02508060802027604

Houle, J., \& Martin, M. (2011). Does Intergenerational Mobility Shape Psychological Distress? Sorokin Revisited. Research on Social Stratification and Mobility, 29(2), 193-203. https://doi.org/10.1016/j.rssm.2010.11.001

Hu, R., \& Chen, S. (2012). Social Factors Influencing Peasant Workers' Mental Health (in Chinese). Chinese Sociology and Anthropology, 32(6), 135-157.

Huang, Z. (2005). Understanding China: Social Science That Starts from Practice. Social Sciences in China, 26(1), 83-94.

International Labour Organisation (ILO). (2019). The Need for Social Justice. Retrieved from www.ilo.org/global/standards/introduction-to-international-labour-standards/need-for-social-justice/lang--en /index.htm

Jin, L. et al. (2012). Trans-Local Ties, Local Ties and Psychological Well-Being Among Rural-to-Urban Migrants in Shanghai. Social Science \& Medicine, 75(2), 288-296. 
https://doi.org/10.1016/j.socscimed.2012.03.014

King, R., \& Skeldon, R. (2010). "Mind the Gap!" Integrating Approaches to Internal and International Migration. Journal of Ethnic and Migration Studies, 36(10), 1619-1646. https://doi.org/10.1080/1369183X.2010.489380

Knight, J. et al. (1999). Chinese Rural Migrants in Urban Enterprises: Three Perspectives. Journal of Development Studies, 35(3), 73-104. https://doi.org/10.1080/00220389908422574

Law, W., \& Ho, W. (2004). Values Education in Hong Kong School Music Education: A Sociological Critique. British Journal of Educational Studies, 52(1), 65-82. https://doi.org/10.1111/j.1467-8527.2004.00255.x

Lee, K., Wong, H., \& Law, K. (2007). Social Polarisation and Poverty in the Global City: The Case of Hong Kong. China Report, 43(1), 1-30. https://doi.org/10.1177/000944550604300101

Lee, S. (2016). Massification without Equalisation: The Politics of Higher Education, Graduate Employment and Social Mobility in Hong Kong. Journal of Education and Work, 29(1), 13-31. https://doi.org/10.1080/13639080.2015.1049024

Li, B. (2006). Urban Social Change in Transitional China: A Perspective of Social Exclusion and Vulnerability. Journal of Contingencies and Crisis Management, 13(2), 54-65. https://doi.org/10.1111/j.1468-5973.2005.00457.x

Li, H. et al. (2008). Research on the Psychological Health State, Life Events and Coping Style of the Non-Native Enterprises Workers. Chinese Journal of Behavioural Medical Science, 17(9), 819-820.

Li, L. et al. (2007). The Mental Health Status of Chinese Rural-Urban Migrant Workers: Comparison with Permanent Urban and Rural Dwellers. Social Psychiatry and Psychiatric Epidemiology, 42(9), 716-22. https://doi.org/10.1007/s00127-007-0221-0.

Lin, D. et al. (2011). Discrimination, Perceived Social Inequity, and Mental Health Among Rural-to-Urban Migrants in China. Community Mental Health, 47(2), 171-80. https://doi.org/10.1007/s10597-009-9278-4

Lin, L. \& Ho, Y. (2009). Confucian Dynamism, Culture and Ethnical Changes in Chinese Societies - A Comparative Study of China, Taiwan, and Hong Kong. The International Journal of Human Resource Management, 20(11), 2402-2417. https://doi.org/10.1080/09585190903239757

Liu, X. et al. (2008). Investigation on Mental Health of Peasant-Workers on Duty and Peasants at Home. Chinese Journal of Public Health, 24(8), 923-925.

Liu, L. et al. (2010). A Survey in Rural China of Parent-Absence Through Migrant Working: The Impact on Their Children's Self-Concept and Loneliness. BMC Public Health, 10(32). https://doi.org/10.1186/1471-2458-10-32

Liu, Y. et al. (2009). The Mental Health Status Among Migrant Workers on the Labour Market in Liaoning. Chinese Journal of Health Education, 25(12), 894-896.

Luo, W. et al. (2018). Rural-to-Urban Migration and Adolescent Delinquent Behaviours: Evidence from Hunan and Guangdong in China. Eurasian Geography and Economics, 59(2), 246-266. https://doi.org/10.1080/15387216.2018.1496346

Ma, J. et al. (2009). Perceived Family Functioning and Family Resources of Hong Kong Families: Implications for Social Work Practice. Journal of Family Social Work, 12(3), 244-263. https://doi.org/10.1080/10522150903030147

Ma, X. (2001). Bullying and Being Bullied: To What Extent are Bullies also Victims? American Educational Research Journal, 38(2), 351-70. https://doi.org/10.3102/00028312038002351

Marshall, G., \& Firth, D. (2003). Social Mobility and Personal Satisfaction: Evidence from Ten Countries. The British Journal of Sociology, 50(1), 28-48. https://doi.org/10.1111/j.1468-4446.1999.00028.x

May, C. (2011). Why Justice is Important. In D. Connell, \& Q. Grafton (Eds), Basin Futures: Water reform in the Murray-Darling Basin (pp. 149-162). Canberra: ANU Press.

Mijs, J. (2016). The Unfulfillable Promise of Meritocracy: Three Lessons and Their Implications for Justice in Education. Social Justice Research, 29(1), 14-34. https://doi.org/10.1007/s11211-014-0228-0

Morris, P. (1997). School Knowledge, The State and The Market: An Analysis of the Hong Kong Secondary School Curriculum. Journal of Curriculum Studies, 29(3), 329-350. https://doi.org/10.1080/002202797184071 
Naudet, J. (2008). "Paying Back to Society": Upward Social Mobility Among Dalits. Contributions to Indian Sociology, 42(3), 413-441. https://doi.org/10.1177/006996670804200304

Payne, G. (2013). Models of Contemporary Social Class: The Great British Class Survey. Methodological Innovations Online, 8(1), 3-17. https://doi.org/10.4256/mio.2013.001

Poon, L. (2012). The Piano as Cultural Capital in Hong Kong (Doctoral thesis). The University of Hong Kong, Hong Kong.

Qian, S. et al. (2008). The Mental Health Status of 232 Hennan Migrant-Workers and Its Influencing Factors. China Journal of Health Psychology, 16(4), 459-461.

Qing, J. (2011). From Mind Confucianism to Political Confucianism. In R. Fan (Ed.). The Renaissance of Confucianism in Contemporary China (pp. 17-32). London: Springer.

Savage, M. et al. (2013). A New Model of Social Class? Findings from the BBC's Great British Class Survey Experiment. Sociology, 47(2), 219-50. https://doi.org/10.1177/0038038513481128

Savage, M. (2015). Contesting Class Boundaries. Social Class in the 21st Century (pp. 24-53). London: Pelican.

Savulescu, J. (2006). Justice, Fairness and Enhancement. In W. Bainbridge \& M. Roco (Eds.). Progress in Convergence: Technologies for Human Wellbeing (pp. 321-338). Boston, MA: Annals of the New York Academy of Sciences.

Shapovalova, T. (2013). Is Social Capital Really the Capital in Terms of Economics? Socialinis Ugdymas, 2(34), 150-158. https://doi.org/10.1080/00346760110127074

Shek, D. (1997). Family Environment and Adolescent Psychological Well-Being, School Adjustment, and Problem Behaviour: A Pioneer Study in a Chinese Context. The Journal of Genetic Psychology, 158(1), 113-128. https://doi.org/10.1080/00221329709596656

Shek, D., \& Chan L. (1999). Hong Kong Chinese Parents' Perceptions of the Ideal Child. The Journal of Psychology, 133(3), 291-302. https://doi.org/10.1080/00223989909599742

Social Indicators of Hong Kong (SIHK) (2018 July 12). Gini Coefficient. Retrieved from https://www.socialindicators.org.hk/en/indicators/economy/11.6

Sorokin, P. (1927). Social Mobility: Harper's Social Science Series. New York, NY: Harper \& Brothers.

Sorokin, P. (1959). Social and Cultural Mobility. Glencoe, IL: Free Press.

Spires, R., \& Cox, J. (2016). Addressing Social Capital for Disadvantaged Youth: Youth and Teacher Perceptions of a Youth Development Program in Hong Kong. Cogent Social Sciences, 2(1). https://doi.org/10.1080/23311886.2016.1191105

Wang, D., \& Gao, M. (2013). Educational Equality or Social Mobility: The Value Conflict Between Preservice Teachers and the Free Teacher Education Program in China. Teaching and Teacher Education, 32(1), 66-74. https://doi.org/10.1016/j.tate.2013.01.008

Wang, X. (2002). Education in China Since 1976, London: McFarland \& Company, Inc.

Weber, M. (1998). Class, Status, Party. In R. Levine (Ed.), Social Class and Stratification (pp. 43-56). Lanham, MD: Rowman \& Littlefield Publishers.

White, G. \& Goodman, R. (2006). Welfare Orientalism and The Search for An East Asian Welfare Model. In R. Goodman et al. (Eds.), The East Asian Welfare Model Welfare Orientalism and The State (pp. 3-24). London: Routledge.

Wong, Y. (2010). Social Mobility and Social Inequality: The Ambivalence of the Middle Class. Sociological Research Online, 15(2).

Yang, T. et al. (2012). Mental Health Status and Related Characteristics of Chinese Male Rural-Urban Migrant Workers. Community Mental Health Journal, 48(3), 342-351. https://doi.org/10.1007/s10597-011-9395-8

Yao, X. (2000). An Introduction to Confucianism. Cambridge: Cambridge University Press.

Yeh, K. et al. (2013). Filial Piety in Contemporary Chinese Societies: A Comparative Study of Taiwan, Hong Kong, and China. International Sociology, 28(3), 277-296. https://doi.org/10.1177/0268580913484345

Zhan, H., \& Montgomery, R. (2003). Gender and Elder Care in China: The Influence of Filial Piety and Structural Constraints. Gender and Society, 17(2), 209-29. https://doi.org/10.1177/0891243202250734 
Zhan, S. (2011). What Determines Migrant Workers' Life Chances in Contemporary China? Hukou, Social Exclusion, and the Market. Modern China, 37(3), 243-85. https://doi.org/10.1177/0097700410379482

Zhao, Y. (2014). Who's Afraid of the Big Bad Dragon: Why China Has the Best (and Worst) Education System in the World. San Francisco, CA: Jossey-Bass.

Zhong, B. et al. (2013). Prevalence of Psychological Symptoms in Contemporary Chinese Rural-to-Urban Migrant Workers: An Exploratory Meta-Analysis of Observational Studies Using the SCL-90-R. Social Psychiatry and Psychiatric Epidemiology, 48(1), 1569-1581. https://doi.org/10.1007/s00127-013-0672-4

Zhong, B. et al. (2015). Prevalence and Correlates of Major Depressive Disorder Among Rural-to-Urban Migrant Workers in Shenzhen, China. Journal of Affective Disorders, 183(1), 1-9. https://doi.org/10.1016/j.jad.2015.04.031

Zhou, Y. et al. (2017). A Longitudinal Study of the Impact of Occupational Mobility on Job Satisfaction Trajectory: Individual Differences in Neuroticism. In G. Atinc (Ed.), Proceedings of the Seventy-seventh Annual Meeting of the Academy of Management, October 30, 2017. AL.

\section{Copyrights}

Copyright for this article is retained by the author(s), with first publication rights granted to the journal.

This is an open-access article distributed under the terms and conditions of the Creative Commons Attribution license (http://creativecommons.org/licenses/by/4.0/). 